\title{
EMCO \\ "To turn one idea into more shapes than Proteus": The copious use of words in Erasmus and Milton
}

\author{
by Larisa Kocic-Zámbóné
}

The present article aims to present a critical application of Richard Waswo's notion of the "cosmetic" aspect of language in the Renaissance, with a special focus on Erasmus and Milton within a framework of two related issues: Questione della Lingua and Imitatio.

No human body part is so cautiously constrained by Nature than our tongue. Or so Erasmus claims in his Lingua [The Tongue] (1525). For while our eyes are merely covered with "a frail membrane, suited only for sleep", Nature "buried the tongue virtually in a dungeon, and bound it by many bonds" $(1989,268)$. Erasmus also reminds his readers that, in fact, Varro thought the word lingua "tongue" to come from ligare "to bind." And as if this biding were not enough to constrain this protean member, Nature set in its path "the double rampart and barrier of the thirty-two teeth" and, in addition, "the double doors of the lips" (ibid). The reason for this thorough biding of the tongue lies in its ambivalent properties which render it a simultaneous source of malevolent and benevolent discursive agencies:

O ambivalent organ, from which such a great plague of life can spring up for men, and yet from it such benefits could flow, if anyone directed it as they should! [...] For the tongue exercises equal domination whether you wish to save or destroy. [...] The tongue is Ate, strife personified, if it lacks a pilot. It is a horn of plenty, if you use it well. It is Eris, rouser of quarrels, but the same tongue is Grace, who wins good will. It is Erinys, the bringer of all evils, but it likewise calms all things. It is the venom of the asp if it acts with ill will, but a universal antidote if good intentions control it. It is the source of wars and civil strife, but it is also parent to peace and concord. It overthrows city-states and kingdoms, but it also founds and establishes them. Finally it is the deviser of death, but equally the bestower of life. (Erasmus 1898, 365)

$1 \quad$ Isidore of Seville in his Etymologies particularizes this by saying that "Varro thinks that the tongue, lingua, was named from binding food, ligare; others because it binds words [Linguae a lingando cibo putat Varro nomen impositum. Alii, quod per articulatos sonos verba ligat]" (Orig. XI.51; see also Mazzio 1998, 98, 114n19) 
The contrary motion of the tongue, both in respect of its discursive agencies and physical motion, ${ }^{2}$ was a source of anxiety both in pagan and biblical antiquity as seen by the vast number of classical allusions in Erasmus's Lingua. But this was not the only aspect of the anxiety about the tongue - especially in its meaning of language for the initial anxiety was intensified in the Renaissance by the Questione della Lingua: the pertinent question whether (or when) to write in Latin or in a vernacular.

As the name of the Questione della Lingua suggest, Italy was the first to confront the language-question, with Dante pioneering the debate. In Il Convivio [The Banquet] (1304/1307) Dante justifies at length his choice of writing in vernacular Italian and in the process establishes the crucial difference between Latin and the vernacular language: the former is eternal and incorruptible, while the latter is unstable and corruptible, being constantly fashioned and, thus, susceptible to change. So much so, that "in the cities of Italy [...] we find that within the last fifty years many words have become obsolete, been born, and been altered" to the point "that if those who departed this life a thousand years ago were to return to their cities, they would believe that they were occupied by foreigners, because the language would be at variance with their own" (I.5). ${ }^{3}$ For Dante these observations, despite his genuine love and devotion for Italian, establish the sovereignty of Latin, the beauty of which is seen in the harmonious correspondence of its parts. In addition, the parts of a language correspond "more properly" in Latin than in the vernacular, "because the vernacular follows custom [i.e. use], while Latin follows art [i.e. the rules of grammar]" (1.5).

$2 \quad$ For the ambivalence inherent in representations of the tongue in early modern England see Mazzio 1998.

3 Dante here notes his intention to elaborate the matter more fully in a treatise on Eloquence in the Vernacular. And indeed, in February of 1305 Dante was at work on De Vulgari Eloquentia, in which he argues for the establishment of a "illustrious" vernacular that could serve as the medium for a national literature. Richard Waswo blames the relative obscurity of the treatise on the fact that it was written in Latin (1987, 51-52). 
All of the above mentioned features established Latin as the decisive scholarly tool, the constancy of which was sharply contrasted with the versatility of the tongues in use. It was the sine qua non of the educated and, in John K. Hale's words, "a triple gateway: to preferment, to the intellectual life of antiquity, and to active membership of the European intelligentsia" $(2005,2)$. Its universal gravitational pull "enabled humanist to study and teach everywhere [...] and no humanist ever voted for the vernacular at the expense of Latin's portability" (3). Those who choose to write in their vernacular tongues where, therefore, aware of a certain loss, a sense of sacrifice, especially in respect to the durability of their work. ${ }^{4}$ Even in England, where the English vernacular supplanted Latin (and French) as the language of law and government by 1500 and by 1540 even the liturgical language of the church (4), the notion of eternal Latin versus transitory vernacular persisted well into the seventeenth century, as evinced by Edmund Waller's poem "Of English Verse" first published in 1668:

Poets may boast, as safely vain, Their work shall with the world remain;

Both bound together live or die,

The verses and the prophecy.

But who can hope his line should long

Last in a daily changing tongue?

While they are new, envy prevails,

And as that dies, our language fails.

[...]

Poets that lasting marble seek

Must carve in Latin, or in Greek;

We write in sand; our language grows,

And like the tide our work o'erflows...

(Waswo 1987, 57)

$4 \quad$ Montaigne, thus, writes in his Essays: "I write for few men and few years. If duration were the question, the work should be committed in more rigid language. Given the continual variations that ours has undergone up to now, who can hope it will be used in its present form fifty years from now? Day after day it is slipping through our fingers, and in my lifetime half has already altered. We say that now it is perfect. As each century said the same for its own. I take care not to stop there as long as it pursues this constant flight and deformation" (3.9.982; in Jeanneret 2001, 178) 
In these instances of anxiety about the mutability of the native tongue one can observe a change in the assumed relation between language and meaning. The two extreme points of the Renaissance semantic shift — referential versus relational language, as described by Richard Waswo in Language and meaning in the Renaissance — are already discernible, I believe, in Dante's Banquet. On the one hand, the relationship between language and meaning in case of Latin is ontologically bound: "language, which is constituted to express human thought, is virtuous when it does this, and more completely it does this, the more virtuous it is" (Convivio I.5). Hence, the supremacy of Latin, for it "expresses many things conceived in the mind which the vernacular cannot" because "the vernacular follows custom [usus] while Latin follows art [arte]" (ibid). Latin is, therefore, the referential language par excellence, since it "cannot undergo change" and whose transmission is consequently uninterrupted by time or space: "Thus in the ancient Latin comedies and tragedies [...] we find the same Latin as we have today" (ibid). On the other hand, the correspondence of words to preextant things ("things conceived in the mind") is compromised in the case of vernaculars by their constant shifts and alterations in following custom/use instead of art/grammar.

However, it was in a century after Dante that the semantical shift could take its real effect. For the writers to follow the lead of Dante and to choose their vernaculars over Latin, the very confidence which Dante had in the incorruptible transmission of Latin at the beginning of the fourteenth century had to be shaken by an awareness that a historical rapture had taken place, and that not even Latin was a safeguard against loss and change.

That language had a past was something even generations before the Renaissance were aware of. Yet it was, in Waswo's words, "[ $t]$ he 'rebirth' of the classical past through the acutely self-conscious midwifery of Renaissance humanist" that "created an awareness of the historical context of usage in language that gradually came to be treated as semantically constitutive" $(1987,79)$. Lorenzo Valla in particular played a crucial role in forming this awareness. Renowned in his own day as the author of the Elegantiae linguae Latinae (1471) 
- an elaborate account of the grammar, diction and style of the classical Latin - Valla lay the foundations of a philology that challenged the received semantics of reference. His philological methodology was dazzlingly simple in concept (although not in execution). Aiming to recover the eloquence of Roman antiquity, Valla conducted an empirical survey of how classical writers actually used their Latin and, consequently, exposed a temporal distinction in syntactic and lexical usages of Latin between ancient Rome and medieval Europe. ${ }^{5}$ Waswo summarizes the philosophical and theoretical import of his work, and the challenge it posed, as:

the profoundly disturbing demand for the literal re-vision not merely of what we think but of how we are able to think anything at all. [...] Valla attempted to conceive of signification as different from, other than, the res significata whether in the world or in the mind: as a function of words and their use, not as their objects of reference. For him, words had cognitive force, and meaning was an activity multiply determined by grammatical relationships and historical contexts. (1987, 111-112)

Valla contemporaries might not have understood the impact of his work in full, yet the diffusion of his historical interpretative practice was widely felt in debates on rhetoric, on emerging protestant biblical hermeneutics and, naturally, on language. ${ }^{6}$ It was $5 \quad$ Valla applied the method most notably to expose the Roman imperial decree, the Donatio Constantini —ensuring the papal dominance over the Western Roman Empire as the legacy of Constantine's donation, transfering the authority over Rome and the western part of the Empire from the Emperor to Pope Sylvester I. - as a historical fraud employing a vernacular style conclusive of a much later era than its alleged provenance. Christopher B. Coleman, the English translator of Valla's proof, De falso credita et ementita Constantini Donatione declamatio (1439/1440), noted its significance thus: "[F]or the first time, [Valla] used effectively the method of studying the usage of words in the variations of their meaning and application, and other devices of internal criticism which are the tools of historical criticism today" (1922, 3; in Waswo 1987, 88).

6 Just how late are the notions sowed by Vala in their ripening, see Tibor Fabiny's article, "Literature: A New Paradigm of Biblical Interpretation" (Fabiny 1999, 11-29). In it Fabiny confirms the paradigm-shift of biblical interpretation that turns to language and puts the locus of meaning in the text itself as opposed tot he theological and the historical apporach in which the locus of maning was/is "behind the text, either in the 'doctrine' or in the 'event" (14). Following Northrop 
through him, as Waswo elsewhere noted, "that humanist philologist discovered time" and, in turn, "it was history, by observing the fact of change in all languages, that made it possible to liberate and dignify the vernaculars, to perceive their status and potency as equal to those of Latin and Greek" $(1987,59)$.

Similarly, Michel Jeanneret, in his study of Renaissance's "transformist sensibility", notes the opportunity and challenge perceived in the aging of the antique heritage by scholars promoting the vernacular. In his assessment of this challenge, Jeanneret resorts to a Proteus-reminiscent description of language struggle:

[I]in spite of frustrations, most writers preferred to struggle with a flexible living tongue rather than serve a rigid dead language. The Latin conserved in the Middle Ages was certainly impure, but active and flexible. With influence of philologists and Ciceronian purists and an awareness that a historical rupture had taken place, Latin [of the antiquity] became an untouchable relic, a monument out of reach of the moderns. Reviving that inert object would mean surrendering to the fatality of an invariable language, abdicating the freedom to act on language and adapt it to new demands. (2001 181-182).

The same liberating effect of the use of vernaculars, as noted by Waswo and Jeanneret so far, is the final conclusion John K. Hale comes to when expounding the language choices Milton had to face. ${ }^{7}$ For although Milton was inclined to seek, as his contemporary Edmund Waller wrote, the "lasting marbles" of poetry, and quite capable of

Frye's initiative of perceiving biblical language as "the language of proclamation, 'the vehicle of revelation", Fabiny maintains that biblical language is "much closer to the poetic-figurative rather than to a plain, referential 'literal' language... As opposed to the denovative- referential language of science, biblical language, especially that of the prophecies, is emotive, associative and connotative" and "radiates words with power, the purpose of its rhetoric is to affect, transform and change its reader" (15).

$7 \quad$ Hale has exounded the impact of Milton's many languages in two book length studies, in Milton's Languages: The Impact of Multilingualism on Style (2005) and in Milton as Multilingual (2007). The first book focuses on the multilingualism of Milton's English works, while the latter book deals more exclusively with Milton's Latin, Greek, Italian and Hebrew texts. 
carving "in Latin, or in Greek", he, nevertheless, chose "to struggle with a flexible living tongue" of his own. In The Reason of Church Government Urged against Prelaty (1642), book two, he divulges of himself the following confession/vocation:

I began thus far to assent [...] that by labour and intense study, (which I take to be my portion in this life,) joined with the strong propensity of nature, I might perhaps leave something so written to after-times, as they should not willingly let it die. These thoughts at once possessed me, and these other; that if I were certain to write as men buy leases, for three lives and downward, there ought no regard be sooner had than to God's glory, by the honour and instruction of my country. For which cause, and not only for that I knew if would be hard to arrive at the second rank among the Latins, I applied myself to that resolution, which Ariosto followed against the persuasion of Bembo, to fix all the industry and art I could unite to the adorning of my native tongue; not to make verbal curiosites the end, (that were a toilsome vanity,) but to be an interpreter and relater of the best and sagest things, among mine own citizens throughout this island in the mother dialect. (Hughes 1957, 668)

When Milton writes about becoming "an interpreter and relater of the best and sagest things", he has in mind the practice of Imitatio ${ }^{8}$ that is, "emulation", not some slavish copying. It entails simultaneously the ambition for originality and the following of proven exemplars, as in the opening invocation of Paradise Lost, where Milton's "Things unattempted yet in Prose or Rime" (1.16) echoes Ariosto's "Cosa non detta in prosa mai, né in rima" (Orl. Fur. 1.2) only to prove himself the more original in distinguishing his theme from those of previous epic poems, including Orlando Furioso (PL 9.25-41). Indeed, it is the question of Imitatio in relation to the Questione della Lingua which brings us back to Jeanneret's observation about writers struggling with their protean mother tongues, and how it applies to Milton.

8 I follow Hale in rendering Imitatio with an upper-case I, hence, distinguishing ,the Roman idea from Aristotle's mimesis on the one side and from Plato's derogatory sense, 'imitativeness', on the other' (2005a, 208n2). 
It is certainly not a simple application. John K. Hale, who is without doubt the single expert among contemporary Milton scholars on Milton's multilingualism, devotes a whole book to the complexity of Milton's language choices. ${ }^{9}$ Relaying on his excellent introduction, I will try to encapsulate his observations pertaining to my argument.

Taking into the account the rawness and the impurities of a mother-tongue (in Milton's age), Hale wonders if Imitatio could not work better by vernaculars than by Latin. After all, vernaculars did "offer greater scope for originality, right down at the cellular level, of words, phrases, lines of verse - the levels where poetry is alive or most dead" $(2005,11)$. But despite the challenge posed by the vernaculars, the choice was not an obvious one. Hale, building on Ann Moss's argument about the deeply personal and anxious dimension of bilingualism ${ }^{10}$, claims that humanists " $\mathrm{did}$ not need to choose once and for all (especially as Latin was their 'mistress'!)" (14). The humanists, Milton included, went on writing in Latin for some purposes. Vernaculars were favored for endeavors of high ambition, like poetry, but more often than not the announcements of those ambitions were made in Latin, along with the defenses for using vernaculars. When the goal was "European or pedagogical consumption", their choice was again Latin (6). The choices of languages, thus, "resulted in complexities, paradoxes, changes and revisions of mind within the clear main current flowing away from Latin" (11). "The texts of the humanist and their vernacular counterparts seem to draw from their very uncertainties, from their protean shifts of style and intellectual contexts, an unfailing supply of color and energy" (Castor \& Cave 1984, xvi; in Hale 2005, 11).

Therefore, in Hale's view, Milton "did not give up his languages", rather, "the interinanimating of his languages increased [...] until his languages came to intersect where they could best intersect, within his English" (57).

In order to illustrate the not so easily disposed dilemma of language choice, Hale turns to intertextuality, because "it works at 9 The already mentioned Milton's Languages: The Impact of Multilingualism on Style.

10 Moss 1994, 61-74. 
such a local level that it is the nuts and bolts of Imitatio: in the feeling of palimpsest in individual words, phrases and lines of verse, the poetic texture honours the ancient world and the post-Roman reception" (Hale 2005, 12). The creation of such a palimpsest comes "more readily" in Latin by using words, phrases, or even whole lines from Latin masters. Already in vernaculars abounding in Latin-derived words the task becomes harder, and increasingly so in English. Nevertheless, Hale does not consider it a foregone conclusion whether one chooses (or chose) to do what is harder, or what can be more complete. In particular, he sees Milton "choosing what gave him the more options", that is, English, since it "gave him almost all the options which Latin gave, and some which Latin could not" (12). Hale summarizes and explains this as follows:

Using Latin words and metres to emulate Roman exemplars like Virgil, Ovid, Horace, he would so readily call into view their words that too much might show through the palimpsest; not necessarily dwarfing him, but obscuring his own sense or distracting from it (like a simile whose vehicle crushes the tenor). The challenge was to ensure that his thought commanded more attention than did the words or allusions [...] Composing in English produced the reverse dilemma. In English Milton could not summon up Virgil or others so easily or casually, because he could not use so many Latin-derived words within English. The task was apparently far harder than in Latin. Yet Milton gains the option to foreground the thought and not the words, or the interaction of thoughts with words, and both options enabled an interaction of infinite variety. The more stringent needs of English Imitatio were, finally, more liberating. (2005, 12-13)

But one did not experience freedom of Imitatio only when writing in the vernacular. With the new sense of history, and the awareness of a past irrevocably lost (an awareness fostered by Valla's philological method), antiquity receded and vanished with the very moment of its rediscovery. But instead of mourning for its loss, and nourishing negative nostalgia, most humanists engaged in the salvaging of its goods by "inserting a measure of novelty in the hiatus" 
(Jeanneret 2001, 142). As if replaying the encounter between Greece and Rome, they "aspired to be both victors and vanquished, free and faithful, different and differential like the Romans" (ibid). Consequently, imitation was seen, on the one hand, as "mimetic devotion" minimizing the effect of history, and, on the other hand, as "exploitation of the eclipses of the past" for present use and benefit (ibid). ${ }^{11}$

The best way to illustrate the bifurcated character of Renaissance Imitatio is to evoke the sixteenth century Ciceronian controversy. On the one hand, purist like Cardinal Bembo (1470-1547), Sadoleto (1477-1547), Julius Caesar Scaliger (1484-1538) and Etienne Dolet (1509-1546), have come to look upon Cicero as the only definitive standard for Latin composition. They went as far as to use only the words and constructions found in Cicero's works, applying any circumlocution to achieve this end. Paul Monroe, in an introduction to Erasmus's Ciceeronianus, list two main tenets of the Ciceronians: 1) the existence of "an absolute standard in the use of language" (1908, 14), and, since that absolute standard was most perfectly achieved

11 Milton's choice to write in English is informed with another aspect of liberty: not merely of language, but of content as well. As he says, he chose English not our of "verbal curiosites" which "were a toilsome vanity" but "to be an interpreter and relater of the best and sagest things" (Hughes 668). In Of Education, first published in 1644 and then republished in Poems, etc upon Several Occasions 1673, when elaborating the end of language learning, Milton confirms the same saying: "the language is but the instrument conveying to us things useful to be known" (Hughes 631). He goes as far as to even make a short jab at the linguist who "pride[s] himself to have all the tongues that Babel cleft the world into" - an achievement Milton finds no more praiseworth than the learning of "any yeoman or tradesman competently wise in his mother dialect only" if not paired with the study of "the solid things in them [languages] as well as the words and lexicons" (ibid). What matters to Milton is the salvaging of thoughts, the wisdom oft he ancients, the very reason why „we are taught the languages of those people who have at any time been most industrious after wisdom" (ibid). It is usefull here to quote Hale on an emphasis of Milton's language-learning, namely, the exercise of translating not merely from original language to target language, and vice versa, but "to go round a cirlce of languages, finaly back to the original." The value of this "circle" method Hale sees in that "words and ornaments are bound to be left behind" while "the thought is seized, ready to be expressed in whatever tongue. Paradoxically, then, so verbal an exercise trains one in skill of thought, as much as skills of words" $(2005,10)$. 
by Cicero, 2) "a proper style of writing Latin in any age and for all purposes was to be formed by direct imitation of the master" (1908, 15). Hence, they defined a rational aesthetics founded on presumably universal principles, taking no heed of the passage of time and the changes it necessarily brought, favoring instead a constant and universally applicable ideal ${ }^{12}$ unaffected by place or time. On the other hand, Anti-Ciceronians like Poliziano, Gianfrancesco, and Erasmus, opposed purist because their exclusive zeal for Cicero's style made of Latin a "dead" language, devoid of flexibility and accommodating capacities that would suit it for all sorts of topics, including those not addressed by Cicero himself. ${ }^{13}$ In Dialogus Ciceronianus [The Ciceronian] (1528) Erasmus argument against the Italian purists amount to a wide-ranging discussion about the nature of Imitatio. The Imitatio Erasmus approves of is an imitation

not enslaved to one set of rules, from the guidelines of which it dare not depart, but imitation which gathers from all authors, or at least from the most outstanding, the thing which is the chief virtue of each and which suits your own cast of mind; imitation which does not immediately incorporate into its

12 The universal application of the prefect Ciceronian style was somewhat contested by the nacionalistic attitude of Ciceronianism which was primarily an Italian phenomenon, and whose proponents claimed that "only Italians had the true gift of the Latin tongue; other nations, they thought, were automatically precluded from writing Latin of a quality fit to be called Ciceronian" (Rummel 2003, 123). One finds this notion persevering well unto Milton, perhaps because of his inclination towards Ciceronianism, for we read the following recommendation concerning Latin pronounciation: "[Latin] speech is to be fashioned to a distinct and clear pronunciation, as near as may be to the Italian, especially in the vowels. For we Englishmen, being far northerly, do not open our mouths in the cold air wide enough to grace the southern tongue, but are observed by all other nations to speak exceeding close and inward; so that to smatter Latin with an English mouth is as ill a hearing as law French" (Hughes 1957, 633). The selfsame notion is what compels Milton to record with considerable pride his success as a poet among his Italian friends in The Reason of Church Government, receiving "written encomiums, which the Italian is not forward to bestow on men of this side of Alps" (Hughes 1957, 668).

13 The moral and religious effect of such blind devotion to Cicero was the primary reason for Erasmus' diatribe against Ciceronianism, for in their servile adherence to the exact words of Cicero they called God the Father Jupiter Maximus, Jesus Apollo, etc. Cardinal Bembo went as far as to warn Sadoleto "to beware lest his style be corrupted by reading the Epistles of St. Paul" (Monroe 1908, 9). 
own speech any nice little feature it comes across, but transmits it to the mind for inward digestion, so that becoming part of your own system, it gives the impression not of something begged from someone else, but of something that springs from your own mental processes, something that exudes the characteristics and force of your own mind and personality. Your reader will see it not as a piece of decoration filched from Cicero, but a child sprung from your own brain, the living image of its father, like Pallas form the brain of Jove. Your speech will not be a patchwork of a mosaic, but a lifelike portrait of the person you really are, a river welling out from your inmost being. (Rummel 2003, 133).

Instead of uplifting one perfect model/standard, Erasmus and the Anti-Ciceronians defended a freedom of choosing and combining from several different models/standards. But more than that, they emphasized the internalization of what they have gathered, through a process that would assimilate the source beyond recognition and exuding, hence, "the characteristics and force" of one's own personality. Jeanneret at one point claims that Anti-Ciceronians "accepted anachronism as a gauge of freedom, a space for creation and self-assertion" (Jeanneret 2001, 243). I am somewhat dubious of this claim, precisely because the emphasis Jeanneret puts on assimilation and transformation. On the one hand, the Anti-Ciceronians were conscious of the temporal distance that separated their world from the world of Antiquity. "Wherever I turn I see things changed, I stand on another stage, I see another theater, yes, another world" (Erasmus 1908, 62). Hence, instead of imagining in the place of the contemporary Christian audience the Roman Senate and employing the very words of Cicero, they imagined how Cicero would speak if he were to live in their age. ${ }^{14}$ Liberated from its genuine (and unavailable) historical context, Cicero (and the rest of Antiquity), thus, became their contemporary in an imaginary dialogue that varied according to cultural settings, themes

14 "[I]f Cicero were alive now and endowed with such genius as he was then, with such sill of speaking, with such knowledge of our times as he had of his own, if he were inflamed with such zeal toward the Christian state as he showed for the Roman City and the majesty of the Roman name, he would speak today as a Christian among Christians" (Erasmus 1908, 70 et seq.). 
and persons engaging in it. But, on the other hand, Anti-Ciceronians were loath to commit practical anachronism. "Immoderate love for Cicero deceives many, because to adapt the language of Cicero to an entirely different theme [one he did not address] is to come out unlike him" (Erasmus 1908, 77). The "surpassing" element in their practice of Imitatio liberated them from mere repetition of and subjection to the original, but it also makes the description of their practice as anachronistic somewhat out of place. ${ }^{15}$

Simply put, Imitatio in their praxis was based on the metamorphic conception of a work of art, preventing mere duplication. In order to avoid the trap of repetition and subjection, the model one imitated was interiorized and absorbed to the point when it became an integral part of the imitator's system and, hence, indistinguishable from it. This way, the division between past and present was suspended, and one (if gifted) produced a unique voice out of many. And not only that. The division between writer and reader was also suspended, for this way the author was seen as reader appropriating and transforming source-texts (Jeanneret 2001, 241).

Reading, thus, becomes writing, and the metamorphosis from one to the other was often described in terms of digestive metaphors going back to antiquity. The bee metaphor in particular emphasizes the process of assimilation and transformation. One ought to follow the example of the bees, says Seneca, in sifting whatever one has gathered from a varied course of reading and "so blend those several flavours into one delicious compound that, even though it betrays its origin, yet it nevertheless is clearly a different thing from whence it came" (Ep. 84.5). As in the production of honey, the food consumed $15 \quad$ In this respect, I have found Richard Rorty's observation on rational and historical reconstruction of philosophy quite useful. He claims that the two genres of the historiography of philosophy, namely, historical and rational reconstructions of philosophy, can never be quite independent, because, one cannot reconstruct what dead thinkers would have said to their contemporaries (historical reconstruction) unless we try to relate his thoughts to what we ourselves might want to say (the anachronisitc endeavour of rational reconstruction), hence, treating them as our own contemporaries with whom we might exchange views (1984, 49-56). Erasmus certainly exhibits both reconstructions, when expressing an awareness of Cicero's historical context and, at the same time, imagining Cicero as his own contemporary. 
must change from its original form to become tissue and blood. Hence, in case of food nourishing our "higher nature", we must "see to it that whatever we have absorbed should not be allowed to remain unchanged, or it will be no part of us. We must digest it; otherwise it will merely pass into the memory and not into our very being" (Ep. 84.6-7).

Erasmus also employs the apian metaphor in his struggle against the Ciceronians, emphasizing both its collecting/gathering and the creative/transformative aspect. Milton, however, makes no direct allusion to it, but employs digestive metaphors which emphasize the importance of transformation, although, in a rather complicated way.

In The Doctrine and Discipline of Divorce (1643/1644), Milton presumes the reason why custom among teachers and masters (like virtue and conscience) attracts the most disciples and is considered the best instructor:

because her method is so glib and easy, in some manner like to that vision of Ezekiel rolling up her sudden book of implicit knowledge for him that will to take and swallow down at pleasure; which proving but of bad nourishment in the concoction, as it was heedless in the devouring, puffs up unhealthily a certain big face pretended learning mistaken among credulous men for the wholesome habit of soundness and good constitution, but is indeed no other than the swollen visage of counterfeit knowledge and literature... (Hughes 1957, 696-697)

According to Peter M. McCluskey, Milton here "shows that if food is knowledge, then bad knowledge causes indigestion" (1997, 229) resulting in flatulence of folly; flatulence "being the symbol of corrupt doctrine" (228). However, he does not quote the whole passage and, hence, omits the reference to Ezekiel which perplexed Hughes: "The roll symbolized the prophet's message, and Milton's use of it here hardly harmonizes with its Biblical context” (1957, 696n3). I assume that Hughes' thoughts on custom's "sudden book of implicit knowledge" were similar to that of McCluskey in perceiving it as false 
teaching per se. In reference to reading, Milton in Areopagitica permits that " $[\mathrm{b}]$ ad meats will scarce breed good nourishment in the healthiest concoction", nevertheless, he confidently claims that "wholesome meats to vitiated stomach differ little or nothing from unwholesome" (Hughes 1957, 727). Moreover, he notes that bad books "to a discrete and judicious reader serve in many respect to discover, to confute, to forewarn, and to illustrate" (ibid). What matters, thus, is not what enters into a man, be it bad or good, but rather the process of digestion - for even Ezekiel prophecies might prove "of bad nourishment in the concoction" (italics mine). Custom causes flatulence not necessarily because of its unhealthy content, but because it is "swallow[ed] down at pleasure" in a "heedless devouring" (696). Hence, those puffed up with custom are envious and censorious of "aught that sorts not with their unchewed notions and suppositions" (697 - italics mine). The digestive process starts in the mouth with chewing, ${ }^{16}$ and we should, as Quintilian notes, "consign our food to our stomach only when it is masticated and almost dissolved, in order that it may be easier of digestion" (Inst. X.1.19). ${ }^{17}$ Hence, in The Doctrine and Discipline of Divorce, custom's book is a "book of implicit knowledge" for those that gorge on it, swallowing it "uchewed", and, consequently, sporting a "swollen visage of counterfeit knowledge and literature." As Raphael warns Adam in Book Seven of Paradise Lost: "Knowledge is a food, and needs no less / Her Temperance over Appetite", otherwise it oppresses "with Surfet, and soon turns / Wisdom to Folly, as Nourishment to Winde" (126-130). ${ }^{18}$

16 On Renaissance notions of physical digestion see Albala 2002, 54-66 (especially p. 56 on chewing).

17 Quintilian speaks of reading in terms of digestion. In the passage quoted from Instituto oratoria, he accentuates the freedom in reading as opposed to speech which "escapes us with the rapidity of oral delivery." Reading, thus, allows for carefull deliberation equated with chewing, since one can commit to memory and reserve for imitation what one has read "not when it is in a crude state, but after being softened, and as it were triturated, by frequent repetition" (X.1.19).

18 As "unchewed" devouring of custom leads to implicit knowledge, so does that of Scripture lead to implicit faith. Milton in Of True Religion notes, that implicit faith comes from "much hearing and small proficience, till want of fundamental knowledge easily turns to superstition or popery" in the same way to implicite faith" and reminds his readers of Eph 4:14 $(1835,565)$. The extent to which Milton uses the images of flatulence (see McCluskey 1997, 227-238) it is hard to 
The assimilation and transformation of the source-text, therefore, depended on its mental digestion. Indeed, the physiological meaning of the verb digest is listed only as the fourth in the OED, and is preceded by meanings like consider, to settle and arrange methodically, to reduce into a systematic form, to classify, and also to divide and dispose, to distribute (s.v. digest $3 ; 2 ; 1) .{ }^{19}$

Milton's famous dragon's teeth comparison in Areopagitica deserves to be mentioned here too. "I know that they [books] are as lively and as vigorously productive as those fabulous dragon's teeth; and being sown up and down, may chance to spring up armed man" (Hughes 1957, 720). Catherine Gimelli Martin recognizes in it an almost verbatim paraphrase from Bacon's Advancement of Learning:

the images of men's wits and knowledge remain in books, exempted from the wrong of time and capable of perpetual renovation. Neither are they fitly to be called images, because they generate still, can cast their seed in the minds of others, provoking and causing infinite actions and opinions in succeeding ages [...] that whatsoever motions the spirit of man could act and perform without the organs of the body [...] might remain after death. (1854, 183; Martin 2010, 132)

Bacon is clearly emphasizing the potential of literature to continuously generate, casting new seeds in the minds of others and, hence, provoke and cause actions and opinions in succeeding ages. ${ }^{20}$

imagine "every wind of doctrine" in Eph 4:14 without some repugnant odor (or fishie fume).

19 Jeanneret in The Feast of Words: Banquets and Table Talks int he Renaissance (1991) also notes the combination of physiological with the more general sense of to separate, sort out, order or classify in the sixteenth-century French and in the Latin digerere. He also makes note of digestion as a figure of rhetoric (in Cicero and Quintilian) whereby a general idea is divided into particular points implying classification and setting out (136).

20 One should, of course, note that Bacon puts an equal emphasis on their time enduring capacity as opposed to that of more solid structures, like statues and buildings, which were not „exempted from the wrong of time.” In this respect, what Bacon lauds is contrary to Jeanneret's and my own emphasis on transformation for, in Bacon's words, their capacity of endurance lies in maintaining their original form: "For have not the verses of Homer continued twenty-five hundred years, or more, without the loss of a syllable or letter" $(1854,183)$. 
But Bacon's seeds seem "gentler" than Milton's "dragon's teeth" in that the latter are capable of "springing up armed men." It is a general assumption that Milton took this image from Ovid's story of Cadmus, and in doing so evoked also the image of civil war. ${ }^{21}$ Thus, Martin, following Nigel Smith, recalls Henry Parker's use of the Cadmus myth "for the same political purpose: to show that multiple branches of 'knowledge in the making' are essential to 'the reforming of Reformation itself'" $(2010,132){ }^{22}$ Civil war is similarly the outcome of Joad Raymond's reading, who draws our attention to another aspect of Renaissance book production, namely, that "small books were indeed sewn up and down, being stitched together instead of bound; and that in 1642 stitched book did indeed 'spring up armed men"” $(2003,203)$. However, I would like to suggest another, Erasmian interpretation that seems to me more in line with Milton's particular argument about "lively and vigorously productive" books.

In a dialogue on the right way of speaking Latin and Greek, De recta pronuntiatione (1528) - a topic dear to Milton as well Erasmus connects the myth of Cadmus's sowing the dragon's teeth with the traditional assumption that Cadmus introduced writing to the Greeks. For, as he explains, if one were to look and "count the top teeth and the bottom teeth" in the dragon's mount, one "would find the number of letters that Cadmus introduced" from Phoenicia (Erasmus 1985a, 396). In allegorizing the sowing of the dragon'

21 In Ovid's Metamorphoses, Cadmus, instructed by Athena, sowed the dragon's teeth in to the ground, from which sprang a race of armed men. Cadmus fearing a new battle (he had just slain the dragon whose teeth he sow) prepared to arm for defense, but one of the earth-born cried: "Arm not! Away from civil wars!" A fierce massacre ensued with only five warriors surviving, who later assisted Cadmus in founding Thebes (3.95-137).

22 The context in which Parker refers to the dragon's teeth (and the fact that he writes it with a capital D) suggest the identification of the dragon with Papal Rome: "The main Engineers in the Civil Warre are Papists, the most poisonous, serpentine, Iesuited Papist of the World. And the Papist in Europe either pay for the prosperity of the design, or here contribute some other influence and assistance to it. This warre was not the production of these last two years, nor was England alon the field wherein the Dragon's teeth were sown" (Parker 1643, 9; in Smith 1990, 110). Smith is careful not to draw a too close parallel when noting that the image of dragon's teeth in Milton „becomes the image of active republic, full of vibrant, energetic individuals" (111). 
teeth, Erasmus is not merely explicating on his favorite word, sermo [speech] (for "the word 'say' and 'sow,' sermo and sero, share the same root" [397]) ${ }^{23}$ but providing a vivid, albeit brief, image of his notion of language as praxis: "When they [the teeth] are in their original [alphabetical] order they are inert. Scatter them, sow them, let them multiply, distribute them in different combinations, and they will become alive, active and aggressive" (396-397). In other words, the true potential of the letters is realized only in distribution, in multiplication and in their reorganization in various combinations; only this way can they become a force. The fact that Milton compares books and not letters to the dragon's teeth is not an obstacle to a fruitful application of Erasmus' interpretation. As the fruits of the seed planted provide new seeds for planting, so do books composed of "dragon's teeth" provide new "teeth" for sowing. But for them to rise up armed man, they too must not remain inert in their original form of composition, but must be scattered, sown, and their content distributed in different combination. This is how posterity would not willingly let a work die. "Success does not lie in accomplishment but in the impetus give to posterity [...] the essential pole of the book is in the future, with the recipient who will act as relay, carry on the production and pass it along in turn" (Jeanneret 2001, 211).

23 In the second of the five editions of his New Testament, Novum Testamentum omne (1519), Erasmus made the controversial substitution of sermo for verbum in John 1:1, a change to which Erasmus clung almost obstinately, even in face of bitter opposition (especially, if one considers his mellowing stance on Comma Johanneum, the 1 John 5: 7-8 passage he omitted from the first two editions, but supplied from the third edition (1522) on). As Barnett notes, "Erasmus seldom interests himself in meaning independent of speakers and their performances. For him the speaker speaking seems to be an essential factor in the efficacy of a discourse generally, and [...] particularly important in relation to the degree to which discourse can successfully perform an ethical function" $(1996,558)$. In this contexts, the importance of Erasmus' word choice lies in asserting Christ as the speech of God, reflecting his rhetorical activity; and, consequently, the notion of imitation Christi as speaking eloquently with the objective of "eliciting tears of contrition and inflaming the hearts of their listeners" (545). Waswo sees in this substation of semro (speech) for verbum (word) a reflection of the semantic shift he exposes in Language and Meaning in the Renaissance, for it reveals "the humanist practice of locating meaning less in single, discrete words and more in whole utterances and propositions, larger units that presuppose the semantic importance of usage and context" $(1987,220)$ 
The relevance of a work is, therefore, determined by its reception. The more room a work leaves for the reader to intervene, lending itself to various operations and appropriations, the better. Renaissance authors intuitively understood that the future of their works depended on a collaboration with their readers, hence, they had to appeal to the reader's intelligence and stimulate his imagination. And the best way to engage the mind of the recipient party is by applying variety. For "variety is so powerfull in every sphere", claims Erasmus,

that there is absolutely nothing, however brilliant, which is not dimmed if not commended by variety... Just as the eyes fasten themselves on some new spectacle, so the mind is always looking for some fresh object of interest. If it is offered a monotonous succession of similarities, it very soon wearies and turns its attention elsewhere, and so everything gained by a speech is lost all at once. This disaster can easily be avoided by someone who has it at his fingertips to turn one idea into more shapes than Proteus himself is supposed to have turned into. $(1978,302)$.

The ability to turn an idea into more shapes than Proteus is not useful only in speech acts, but in writing too (although, I will return to the significance of speech later, in conclusion). Especially, since for Erasmus writing was in essence "just silent speech" (1985a, 397). Variety lets the speaker/writer avoid two sources of tedium: tautology, the repetition of a word or phrase, and homoiology, identical repetition with even less variation, both boring the "wretched audience to death" (1978, 302). But variety does not only keep the audience/readers' attention alert. In the Ratio verae theologiae, Erasmus applies protean versatility to Christ himself, noting that variety does not "disturbe this harmony [of Christ], but as a composition of different voices is rendered more agreeable, the variety of Christ makes harmony more complete." ${ }^{24}$

$\overline{24}$ In his Ratio verae theologiae (1518): "Neque vero confundit hanc harmoniam Christi varietas; immo sicut e diversis vocibus apte compositis concentus suavissiumus redditur, ita Christi varietas pleniorem efficit concentum. Sic omnia factus est omnibus, út nusquam tamen sui dissimilis esset" (Holborn 211:28-31). For a discussion of Erasmus's fascination with the protean persona of Christ in the 
In a section of one of his antiprelatical tracts, the Animadversions (1641), Milton argues against a set form of liturgy in a similar fashion. The tract is written as a dialogue between Remonstrant, voicing a selected quote from the opponent, and Milton, offering a polemical reply. The suggestion that prescribed words of a prayer help people be more intent on orison and less distracted is met with Milton asserting the opposite: the continuous use of the same words makes one careless, even sleepy. It is "variety" that "erects and rouses an auditory, like the masterful running over many chords and divisions; whereas if men should be ever be thumbing the drone of one plain song, it would be a dull opiate to the most wakeful attention" (Fletcher 1835, 62). Milton elaborates the same thought in more detail and with more irony when writing Eikonoklastes (first published in 1649 , then again with additions in 1650). He emphasizes the tyranny of prescribed litany and the servility of those following it. Exasperated by the argument that we are all to pray the same words because we pray to the same God, Milton ironically exclaims: "Let us then use but one word, because we pray to one God" (314). Moreover, in a fit of extremes he compares the prescribed words of a prayer to the heavenly manna, which "hoarded up and enjoined us [...] will be found, like reserved manna, rather to breed worms and stink" (ibid). ${ }^{25}$ And although Milton acknowledges that we have duties upon us, and feel the same wants, he adds:

yet not always the same, nor at all times alike; but with variety of circumstances, which ask variety of words: whereof God hath given us plenty; not to use so copiously upon all other occasions, and so niggardly to him alone in our devotion... as [God] left our affections to be guided by his light of his concept on individuality see Bietenholz 1966, 79-89.

25 During their exodus the Israelites were fed by God with manna (Ex 16), an edible substance they had to gather each day anew, for stored up for the next day it "bred worms and stank" (Ex 16:20). The only exception being that of manna provided on the day before Sabbath, which was twice the amount usually gathered and did not spoil the next day to accord the Sabbath ordinance (Ex 16:23-24). It is interesting to note again, how Milton manages to compare the prescribed prayers to manna and, yet, by that very comparison establish the unpremeditated prayer as the true manna whose "new" expressions "God every morning rains down... into our hearts" (Fletcher 1835, 314). 
sanctifying spirit, so did he likewise our words to be put into us without our premeditation; not only those cautious words to be used before gentiles and tyrants, but much more those filial words, of which we have so frequent use in our access with freedom of speech to the throne of grace. (Fletcher $1835,314-315)$

It is no surprise, therefore, that Milton's Adam and Eve offer their orisions each morning

In various style, for neither various style

Nor holy rapture wanted they to praise

Thir Maker, in fit strains pronounc't or sung

Unmeditated, such prompt eloquence

Flowd from thir lips, in Prose or numerous Verse.

(5.146-150).

Moreover, the variety of their prayers reflects the variety perceived in Creation in general, or vice versa:

Aire, and ye Elements the eldest birth

Of Natures Womb, that in quaternion run

Perpetual Circle, multiform; and mix

And nurish all things, let your ceasless change

Varie to our great Maker still new praise. (5.180-184)

Waswo would no doubt delight to know, that Milton too insisted "on the semantic principle of context" $(1987,222)$, that necessitated different words for different circumstances. At the same time, he would also note (although not specifically in this passage but elsewhere in Milton) what he calls the discrepancy between theory and practice in Renaissance language debates. Namely, " $[\mathrm{w}]$ hen language is talked about, it is consciously regarded as the clothing of preexistent meanings, but when language is employed to reflect on its various functions [...] it is often implicitly regarded as constitutive of meaning" (60). The former, Waswo calls the "cosmetic view" while the latter he 
terms the "constitutive mode." The difference is between

regarding language as the clothing or container of thoughts, feelings, objects, and meanings that have a separate existence elsewhere and regarding it as constituting those thoughts, feelings, objects, and meanings in the very act of articulating them - just as a melody in constituted by, and is inseparable from, its sounds and the relations among them. [...] the theoretical opposition between these views is a product of all the subsequent reflection on language that has crystallized clearer issues out of what remained for Renaissance thinkers and writers a rather murkier solution of assumptions. (Waswo 1987, 60-61)

Hence, in his chapter on Erasmus, Waswo praises the humanist scholar for his recipes of variation for implicitly treating "meaning as context- and purpose-dependent", while emphasizing the above mentioned discrepancy since "words are" for Erasmus "still explicitly conceived as semantically cosmetic" as seen in his copious use of the "standard formula — "what clothing is to our body, style is to thought" (1987, 216-217). Milton also applies this "formula" time and time again, and perhaps most prominently in his At a Vacation Exercise in the College. ${ }^{26}$ Furthermore, the practice of giving variety to expression as the quotation from Eikonoklastes suggests ("variety of circumstances, which ask variety of words") is, to use Erasmus' words, "exactly like changing clothes" (Barnett 1996, 552).

However, I think that Waswo's choice of term "cosmetic" is misleading in respect to Renaissance way of thinking about words as clothing thoughts. The adjective "cosmetic" is definitively derogatory in Waswo's use, indicating the subjected status of words in a binary hierarchy with words. It allows words/clothes a mere decorative role, that has no constitutive value. Hence, I don't think that cosmetic(s) appropriately describes what Renaissance thinkers thought clothes

$26 \quad$ Addressing his "native Language” Milton writes: “...haste thee straight to do me once a Pleasure, / And from thy wardrobe bring thy chiefest treasure; / [...] /I have some naked thoughts that rove about / And loudly knock to have their passage out; /And wearie of their place do only stay / Till thou hast deck't them in thy best ar[r]ay" (17-26). 
(and words) do. Clothes do make a man, and they especially did so in the Renaissance. The sumptuary laws, dictated both by the national and local government, and legislating what items of dress could be worn by various ranks of people, were enacted in the spirit of this commonplace. The concern with the proper standard of dress (especially the subversive use of clothes) was no where so accentuated as in the antitheatrical writings of the age. As Cerasano notes:

Accounts of the Elizabethan theater are replete with references to the sumptuary laws and the frequent complaints against players who "jett in their silks" thus aping their social betters. Finally the playing companies were capable of purchasing clothing that individual actors were legally prohibited from wearing except on the stage where they impersonated those who had sold them the clothes, thus "borrowing" both robe and title. $(1994,55)$

However, the issue at question is far more complicated and burrows deeper than simple borrowing of "robe and title." Paraphrasing Deuteronomy, chapter twenty-two, Phillip Stubbes writes: "Apparel was giuen vs as a signe distinctiue to discern betwixt sex and sex, $\&$ therefore on to wear the Apparel of another sex is to participate with the same, and to adulterate the verities of his own kinde" (1583, 73). By borrowing an apparel of a different gender one put one's own gender in jeopardy, for the act meant participation "with the same" with consequential adulteration of one's own true nature. Clothes are, therefore, seen not merely as separable adornments but also as constitutive (participating in) of the very things they clothed, because they were able to adulterate them, that is change them by addition. All in all, I do not see such a discrepancy between the Renaissance theory and practice of language. The theoretical opposition between the referential (Waswo's cosmetic) and relational (constitutive) views is, as Waswo himself notes, "a product of all the subsequent reflection on language" but I am still in doubt whether this subsequent theoretical opposition "crystallized clearer issues", and would positively deny that these issues "remained for Renaissance thinkers and writers a rather murkier solution of assumptions" (see Waswo 1987, 61). 
The reason why one perceives such a discrepancy in the first place is, as noted above, that Renaissance thinkers indeed thought about language doing both: referring to their thoughts and construing them at the same time, just as their metaphors on clothing suggest. And it is precisely this "adulterating" power of clothes/words to change by addition that is facilitated by the ability to turn one idea into more shapes than Proteus.

\section{Works Cited}

BaCON, Francis. 1854. The Wisdom of the Ancients. In Basil Montagu, Esq. ed. The Works of Francis Bacon, Lord Chancellor of England. Vol. 1. Philadelphia: Parry \& McMillan, 271-313.

BARNETT, Mary Jane. 1996. "Erasmus and the Hermeneutics of Linguistic Praxis.” Renaissance Quarterly 49:3, 542-572.

Bietenholz, Peter G. 1966. History and Biography in the Works of Erasmus of Rotterdam. Geneve: Droz.

Castor, Grahame and Terence Cave, eds. 1984. Neo-Latin and the Vernacular in Renaissance France. Oxford: Clarendon Press.

Cerasano, S. P. 1994. "'Borrowed robes,' costume prices, and the drawing of Titus Andronicus." Shakespeare Studies 22:43-64.

Dante, Alighieri. 1998. The Convivio. Transl. Richard Lansing. In The Digital Dante Project. Institute for Learning Technologies at Columbia University. Access: May 13, 2011 http://dante.ilt.columbia.edu/

Erasmus. 1908. Ciceronianus or a Dialogue on the Best Style of Speaking. Trans. Izora Scott. New York City: Teachers College, Columbia University.

ERASMus. 1933. Ratio seu methodus compendio perveniendi ad veram theologiam. In Hajo Holborn and Annemarie Holborn, eds. Desiderius Erasmus Roterodamus. Ausgewählte Werke. München: C. H. Beck'sche Verlagsbuchhandlung, 175-305. 
Erasmus. 1978. Copia: Foundations of the Abundant Style / De duplici copia verborum ac rerum commentarii duo. Trans. Betty I. Knott. In Craig R. Thompson, ed. Literary and Educational Writings 2 (Collected Works of Erasmus vol. 23-24). Toronto: University of Toronto Press, 279-660.

ERASMus. 1985. De recta Graeci et Latini sermonis pronunciationel The right way of speaking Latin and Greek: A Dialog. Trans. and ed. Maruice Pope. In Literary and Educational Writings 4 (Collected Works of Erasmus, vol. 26.). Toronto: University of Toronto Press.

Erasmus. 1989. Lingua/The Tongue. Trans. Elaine Fantham. In Elaine Fontham and Erika Rummel eds. Literary and Educational Writings 7 (Collected Works of Erasmus, vol. 29.). Toronto: University of Toronto Press.

Erasmus. 2003. "Catalogue of His Works / Catalogus lucubrationum.” In Erika Rummel ed. The Erasmus Reader. Toronto: University of Toronto Press, 21-49.

Fletcher, Robert. 1835. Prose Works of John Milton. London: Westley and Davis.

Hale, John K. 2005 (digital ed). Milton's Language: The Impact of Multilingualism on Style. First published in 1997. Cambridge: Cambridge University Press.

Holborn, Hajo and Annemarie Holborn, eds. 1933. Desiderius Erasmus Roterodamus. Ausgewählte Werke. München: C. H. Beck'sche Verlagsbuchhandlung.

Hughes, Merritt Y., ed. 1957. John Milton. Complete Poems and Major Prose. Indianapolis, N.Y.: The Odyssey Press.

Jeanneret, Michel. 2001. Perpetual Motion. Transforming Shapes in the Renaissance from da Vinci to Montaigne. Baltimor and London: The John Hopkins University Press.

Martin, Catherine Gimelli. 2010. Milton Among The Puritans: The Case for Historical Revisionism. Farnham; Burlington: Ashgate. 
Mazzio, Carla. 1998. "Sins of the Tongue in Early Modern England." Modern Language Studies 28:3/4, 93-124.

McCluskey, Peter. 1997. "Milton and the Winds of Foll." In Kristin Pruitt McColgan and Charles W. Durham, eds. Arenas of Conflict: Milton and the Unfettered Mind. Cranbury, NJ; London; Mississauga, Ontario. Associated University Press, 227-238.

Milton, John. 1957. The Reason of Church Government urged Against Prelaty. First published in 1642. In Merritt Y. Hughes, ed. John Milton. Complete Poems and Major Prose. Indianapolis, N.Y.: The Odyssey Press, 640-689.

Monroe, Paul. 1908. "Editor's Introduction." In Erasmus. Ciceronianus or a Dialogue on the Best Style of Speaking. Trans. Izora Scott. New York City: Teachers College, Columbia University.

Quintilian. 1987. Quintilian on the Teaching of Speaking and Writing. Trans. John Selby Watson. Ed. James Jerome Murphy. Carbondale and Edwardville: Southern Illinois University Press.

Raymond, Joad. 2003. "The Literature of Controversy." In Thomas N. Corns, ed. A Companion to Milton. Malden, MA: Blackwell, 191-210.

Rummel, Erika. 2003. The Erasmus Reader. Reprint, first published 1990. Toronto: University of Toronto Press.

Seneca. 1920. Ad Lucilium Epistulae Morales. 3 vols. Trans. Richard M. Gummere. London: William Heanemann; New York: G. P. Putnam \& Sons.

Smith, Nigel. 1990. "Areopagitica: voicing contexts, 1643-5.” In David Loewenstein and James Grantham Turner, eds. Politics, Poetics and Hermeneutics in Milton's Prose. Cambridge: Cambridge University Press, 103-122.

Stubbes, Phillip. 1583. The Anatomie of Abuses. In Frederick J. Furnivall, ed. Phillip Stubbes's The Anatomy of Abuses in England in Shakespeare's Youth, A.D. 1583. London: New Shakespeare Society (1877-1879).

Waswo, Richard. 1987. Language and Meaning in the Renaissance. Princeton: Princeton University Press. 